\title{
TAX EVASION - THE CRIME OF THE „WHITE COLLAR”
}

\author{
Ana Maria Cordoş ${ }^{1}$
}

\begin{abstract}
This paper treats the problem of tax evasion at the present time constitutes a complex social and economic phenomenon, the harmful consequences of this phenomenon to be limited, reduced, to lose the scale, given that it has become clear to everyone that they can not be eradicated. Tax evasion has a direct effect on levels of tax revenue and without delay, which leads directly to imbalances in market mechanisms, as well as enrichment, unlawful, the practitioners of this method of fraud that affects the state and ultimately each of us, honest taxpayers. With several interpretations, names and meanings of this phenomenon, it is normal for him to be and hard to define. It uziteaza phrases such as "fraud, fraud, illegal, international tax evasion, fraud, legal, international tax evasion, fraud by law, the underground economy." Not just the terminology is an element of confusion, but the law ambiguous boundary between licit and illicit very fragile.
\end{abstract}

Key worsd: tax evasion, social relationships, taxpayer, crime.

Jel Codes: E62, G28

\section{Introduction.}

Tax evasion is a very complex phenomenon, in terms of social relations, not least economic and political facing Romania, seen both as a unitary state and as a full member of a federation - here we refer to membership European Union.

Framed specialists in crime attributed to the so-called "white collar criminality", which does not involve violence, perpetrated mainly by people with higher education, tax evasion is tackled from several angles, from case to case, going as so much so that one part of exegetes it as a normal part of economic reality, meant to regulate and to draw attention to shortcomings in the state on its financial system.

\section{Headquarters matter.}

The seat material is contained in Law 241/2005 for preventing and combating tax evasion, a relatively new legislation, which prromulgare was necessary to prevent and fight more effectively for these categories of crime.

The basic idea of which goes to study tax evasion is that the tax ratio, there is a transmission property of a person's property in the state patrimony, binding and free, without haveing the character of penalty and expropriation.

This law has a dual function, on the one hand to advise taxpayers - individuals and legal about the obligation to contribute through taxes to pay public spending and prevent the consequences of sanction if they are exposed to theft the fraudulent tax duties, and on the other hand, constitute the legal instrument under which criminal liability to those engaged in bad faith, breach of the law.

Compared with the previous legislation in this field, Legea.87/1994 to combat tax evasion, the new law 241/2005, to provide four main elements of innovation: the new law establishes that establishes and prevention of tax evasion; -new sanctions were imposed in connection with criminal

\footnotetext{
${ }^{1}$ University "1 Decembrie 1918" Alba Iulia, Str. N. Iorga, No.11-13, Romania, cordosana@ yahoo.com
} 
offenses called for tax evasion, were incriminated more of a danger as crimes; - have defined many terms used in law, - for greater accuracy standard Legal.

The crimes of tax evasion is, in their materiality, criminal damage, but also of danger and can be done iin one of the following ways, in order to avoid the tax obligations:

- Hide the source property or taxable or taxable;

- Omission, in whole or in part, reflect, accounting documents or other legal documents, the commercial operations or revenues;

- Highlighting, accounting documents and other legal documents, the costs were not based on actual operations or reveal other fictitious transactions,

- Alteration, destruction or concealment of accounting documents, memoirs of equipment charged or electronic cash registers or other data storage means;

- Execution of double accounting records, using the documents or other data storage means;

- Avoiding carrying out financial, fiscal or customs by declaring, declaring fictitious or inaccurate declaration on primary or secondary premises of persons tested;

- Replacement, damage or alienation by the debtor to third persons or property seized in accordance with the provisions of the Tax Procedure Code and the Code of Criminal Procedure.

Public expenditure is of interest both for the national community as a whole, insofar as they relate to the overall financial burden of state and administrative-territorial communities, where it refers to costs incurred by local government. Logically, the contribution of citizens in public spending is done by paying taxes. Establish that the constitutional provision establishing the obligation only by law, taxes, fees and other revenues that support the state budget and state social insurance budget, constitute an implicit guarantee of ownership of property of all citizens. More specifically, it should be noted that issues taxable and tax are both individuals and legal persons.

Tax evasion is one of complex social and economic phenomena of the utmost importance that states face today and which seek to limit unintended consequences as much, eradication is virtually impossible. In what follows, we will analyze the general meeting under the heading of crimes of tax evasion, as they are found in matters of law.

According to the Law nr.241/2005 incriminating text, constitute criminal offense not to show the accounting documents and other legal documents, in whole or in part, revenues, or to record charges not based on actual transactions, if resulted in failure to pay or reduce the tax, fee or contribution to the state.

In terms of subjective side, the offense is committed with intent directly or indirectly.

This offense, if committed in the manner omissions (neevidențierea income) can be committed and guilt.

This view was enshrined in legal practice:

Illustrate this effect

The criminal sentence X, Y Court, NM defendant sentenced to 1 year and 6 months imprisonment for tax evasion, retaining the status quo as follows:

The defendant met the administrator of NM SC "......."- LLC, the company with the object of trade-ferrous materials. The company does not have space to store goods were sold on the same day, which was supplying.

During an inspection by the Police and the Financial Guard found that during the years 1996-1997 did not record the defendant NM accounting income, thereby avoiding the payment of such tax by the state.

Thus, in 1996 SC "......."-- Ltd. delivered by two freight companies totaling 198,709,904 lei, for which invoices were issued were not recorded in the accounts of the company by the defendant thereby avoiding to pay obligations to the state budget amounting to Lei 34793713 , of which tax is 4,479,313 lei and lei 30314405 VAT. 
On 7/31/1997, the defendant accounting CG declaration submitted to the Financial Administration which showed that between 01/01/1997 to 06/30/1997 held company has no activity.

The evidence on record that his company supplied with goods worth 79,099,467 lei the two companies as evidenced by the bills.

By not recording these bills, SC "......."- Ltd. was stolen from his tax obligations to the state budget, amounting to $1,004,861$ lei, of which income tax is RON 636,590 and 368,271 lei TVA.

In 1997 the company recorded in the accounts of three invoices representing supply stainless steel electrodes in the amount of 64.015 million lei.

The technical-scientific report showed that the graphic writing on the three invoices and receipts issued by the same company eight to cash value of goods was made by the defendant.

The defendant admitted that he filled that bill and the eight bills, arguing that that company representatives knew not to write. invoices.

From the evidence in question has revealed that one company is a sham, that is false

At the headquarters "......."- SRL SC raised the police several invoices and receipts in white, bearing the stamp of different companies in the country.

By recording in the accounts of the three bills, the company was registered with deductible expenses in the amount of 54.25 million lei.

Since the goods supplied in accordance with the three fictitious invoices were sold, accounting income is outlined in the defendant's burden was retained in the accounts record the amount of 54.25 million lei false charges.

Accordingly, the defendant has the burden of avoiding the payment of withheld tax to the state budget, totaling 37,798,579 lei, of which 5,115,903 lei represents the income tax and VAT is 30,682,676 lei, and the recording false expenses amounting to 54.25 million lei.

It was concluded that the facts meet the elements of the crime accused of tax evasion in form continued.

The defendant's appeal against that decision was dismissed as unfounded, station ZCriminal Tribunal.

Against these judgments, the legal deadline, the defendant appealed, criticizing them for unlawful and unfounded, citing the scrapping prev.de art.385 indicate if section 912 CPC, arguing that they are constitutive elements of the offense, failing to acted intentionally.

The appeal is unfounded.

The incriminating text, constitute criminal offense not to show the accounting documents and other legal documents, in whole or in part, revenues, or to record charges not based on actual operations, they have often resulted in unpaid tax reduction, state tax or contribution.

In terms of subjective side of the offense is committed intentionally or negligently neevidențierii in accounting for income or with intent to commit the second way, the record of false charges.

On the first way to commit the crime used against the defendant that failure to accounting for revenues in order to avoid tax payment by the state, defending it as not intentionally committed the act can not be received, it can be committed negligently, as the law does not punish only intentional perpetration.

The defendant's act of recording expenses that were not based on actual operations, he acted intentionally.

Thus, the defendant made the statement Financiarăbo Administration - contrary to reality, that the company has not conducted during 1.01.1997-30.0.1997 activity, falsified invoices for supplies of goods from two companies, citing fictitious companies, and at the his firm had several blank invoices and receipts that bore the stamp of various companies in the country. 


\section{Conclusion.}

In conclusion we express our view that from the way it is presented and described in the text of the incriminating act of the legislature, in terms of subjective side of tax evasion offense can be committed with intent both direct and indirect intent.

Also in our opinion, if the act is committed in the manner omissions (neevidentierea income), also in terms of subjective side, and the offense can be committed negligently.

\section{References.}

1. Brezeanu P., Marinescu I., 1998. Finante publice si fiscalitate, Fundatiei „Romania de maine" Publishing House, Bucharest

2. Cullis J., Jones Ph., 1998. Public Finance and Public Choice, Oxford University Press

3. Dauphin C., 1999. Ghidul cu adevarat practic al paradisurilor fiscale, Tribuna Editorial House, Bucharest.

4. Dăianu D., Vrânceanu R., 2002. România şi Uniunea Europeană, Polirom Publishing House, Iaşi

5. Drosu- Şaguna D., 2001. Tratat de drept financiar si fiscal, All Beck Publishing House, Bucharest

6. Hoanță N., 1997. Evaziunea fiscală, Tribuna Economica Publishing House, Bucharest

7. Loghin O., Filipaş A., 1992. Drept penal român, partea specială, „Şansa” Ltd. Publishing and Press House, Bucharest

8. Mrejeru Th., Andreiu D., Florescu P., Safta D., Safta M., 2000. Evaziunea fiscala, Tribuna Economica Publishing House, Bucharest

9. Nistoreanu Gh., Dobrinoiu V., Boroi A., Molnar I., Pascu I., Lazar V., 1997. Drept penal. Partea specială, „Europa Nova”, Bucharest

10. Rühl C., Dăianu D., 1999. Tranzitia economică în România - trecut, prezent si viitor, Romanian Center for Economic Policies, Bucharest

11. Voicu C., Boroi A., 2006. Dreptul penal al afacerilor, IIIrd edition, C.H.Beck Publishing House, Bucharest 